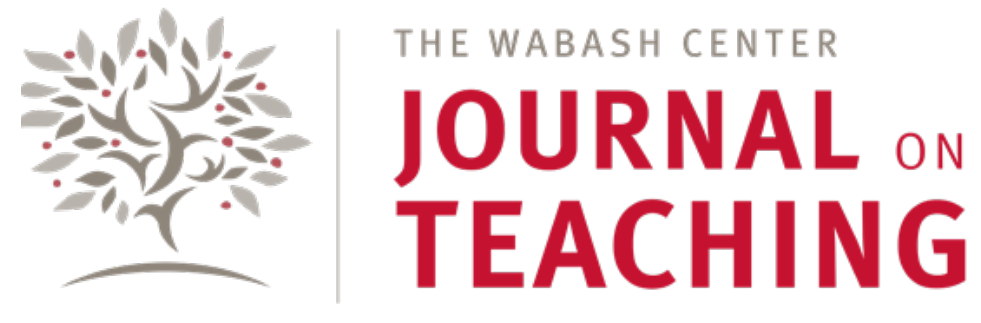

ARTICLE

\title{
Arguing the Mystery: Teaching Critical Thinking in the Theology Classroom
}

\author{
Anthony D. Baker \\ Seminary of the Southwest
}

\begin{abstract}
This article argues that critical thinking and theology belong together. Noting the need for such a combination in the breakdown of conversation between seminary students, the article justifies such a move in a theological anthropology. The author then describes several years of revisions to a Theology 1 course as he attempted to bring together the two goals of teaching theology and teaching critical thinking. The result was a syllabus that demonstrated two central transformations. The first is a "flip" of the classroom, or using the class time entirely for active learning. The second change is the creation of an assignment that walks students from theological conviction to theological argument. The author gives anecdotal and evaluative (grades, student evaluations) evidence to demonstrate the success of these revisions.
\end{abstract}

KEYWORDS

constructive theology, systematic theology, critical thinking, flipped classroom, theological questions

\section{Background}

I began teaching the systematic theology classes at Seminary of the Southwest, an Episcopal institution in Austin, Texas, in 2004. One of my first discoveries was that many students lacked a clear idea of what a good theological debate was. To be precise, they lacked a clear notion of how to structure such a debate so that it did not bring out the vicious aspects of people's characters and so damage relationships. This may sound overly dramatic, but it is worth remembering that the first decade of the twenty-first century was a particularly tumultuous time in the Episcopal Church and the Anglican Communion, as convictions about marriage and human sexuality were, in fact, bringing out the worst in us and often damaging or ruining relationships. Alongside teaching that first year I served on a task force, commissioned by our then Dean, to write a "Conversation Covenant," a framework for critical and charitable dialogue across campus. The document, which the faculty still includes in each syllabus, reminds us that, while "avoiding the issues around which passion and disagreement reside might well be an easier path," still "commitment to remaining in conversation with one another despite our differences is part of our calling as disciples of Jesus Christ” (Seminary of the Southwest 2019).

Remaining in conversation, however, appeared to be difficult for the students in my classes. They liked each other well enough, but somehow discussing the meaning of the cross felt to them a little like showing a colleague your tax return. To borrow language from Howard Stone and James Duke, their theological commitments were deeply “embedded," too deeply for them to find it easy or pleasant to work them out as “discursive” or discussable ideas (1996, 13-21).

In light of this discovery, I began to suspect that part of my role was to teach future priests and others in my classroom how 
to have rigorous, charitable, stimulating, and fun theological arguments. Southwest's Master of Divinity program goals use phrases like "generous intellect" and "self-understanding," alongside proficiency of knowledge and preparedness for leadership, to name qualities we consider essential for ordained ministry. Though I may not have put it this way at the beginning, I have come to see self-understanding and intellectual generosity as keys to proficiency in theological language. That embedded sense of the mysterium tremendum must come out into the connective tissue of thoughtful speech, so that it can offer us more than a haunting backdrop of tacit conviction, opening space for engagement and charitable dialogue.

This meant, I quickly realized, I was going to have do some of my own work in teaching critical thinking, which I, like many graduate students in the humanities, had picked up as a skill without ever being formally taught how it was done. Kathleen Fisher, herself a theologian, defines critical thinking as an "interior process that shapes information into knowledge and then exams it for wisdom" $(2017,10)$. This captures nicely what I wanted for my students: to gather new theological ideas and shape them into coherent articulations, using tools I could give them, so that they could inhabit these ideas as sources of wisdom in their lives, friendships, and vocations. I might only add to her definition that the process is often at least as exterior as it is interior, involving dialogue, the writing out of ideas, and diagraming and revising diagrams.

In my first syllabus drafts, I captured this goal with the following learning outcomes: "Students will produce creative and well-supported arguments for particular Christian beliefs" and "assess contemporary expressions of Christian belief through their encounter with the central teachings of the church." Later, as the goals of generosity and self-knowledge took clearer shape in my theological pedagogy, I revised this to, "Students will formulate multifaceted responses to complex theological questions," and do so "in dialogue with other theologians" (Baker 2018). ${ }^{1}$

\section{Theological Rationale}

I introduced students to these goals with a theological rationale: God makes us to be creatures who grow in the knowledge and love our Creator. While shrugging off the knowledge and opting only for the love might seem simpler, it in fact is a recipe for failure, since, as Augustine teaches, love and knowledge are mutually supportive human energies. We cannot love if we are not concurrently seeking knowledge of what we love, and we cannot know what we do not in some sense love. Further, as I remind my students often, humans are invited to share in the life of God without ceasing to be humans: grace perfects human nature, rather than destroying or replacing it, as Thomas Aquinas puts it. That means that we relate to God with the best human tools we have. One of those tools, though certainly not the only one, is human reasoning. It follows that God invites us to use the same discipline of critical reasoning to know God that we use to know plant cells and jet engines. We know human things with human ways of knowing; we also know the divine one with human ways of knowing. Yes, God is uniquely mysterious; at the same time, God invites us to participate in a path of understanding so that we can both love and know God without ever fully comprehending the one we know and love.

\section{Developing the Course}

Over the years my goal for that first course, of teaching theology as inclusive of "well-supported arguments," has not changed, though my experiments in achieving it have gone through many iterations, with varying degrees of success. Early on I tried some episodic fun: a debate with the same Dean at a bar near campus, with thirty or so students gathered around, over the viability of a doctrine of original sin. (I got a little excited at one point and suggested that he could not coherently believe in Easter if he did not believe in original sin. That may have gone too far, professionally speaking.) In class I assigned medieval style disputations a few times a semester, often held out in the central lawn of campus so other students, faculty, staff, and occasionally trustees or visitors could listen in. For these events, I would assign a yes/no question, and then pick students to argue both sides. I would then come to the front, try to rehearse the best exchanges I heard, and then offer my respondeo quod, an answer crafted to do justice to the arguments aired for and against.

Through the several years that I used this tool, I found that I kept searching for ways to make the disputations more useful in practicing (for students) and assessing (for me) the necessary skill of arguing well. This meant, in part, minimizing the sense of spectacle. We left the lawn and stayed in the classroom. I banned costumes (yes...). I assigned more of them, so that we were eventually doing them nearly once a week. I even altered the syllabus rather drastically, inserting a two-week unit on the

1 The syllabus for “Constructive Theology” Spring 2018 (Baker 2018) is available at https://www.wabashcenter.wabash.edu/selected-resources/?post_ids=229353. 
logic of argumentation. We read chapters from Nancey Murphy's excellent book Reasoning and Rhetoric in Religion (2004), and I assigned the exercises. We diagramed arguments on the white board during class. For those two weeks, had you walked into Theology 1, you may have heard the occasional reference to resurrection and ascension, but the energy of the classroom gathered around words like "warrant," "backing," and "internal rebuttal."

Over time I began to discover, both through student responses and my evaluation of their work, that I was asking too much and therefore not achieving enough. It is hard enough to get a basic grasp of theology in a semester course; I was asking them - many for the first time - to also get a basic grasp of the grid of concepts and practices of critical thinking. I wanted to give my students the freedom to recognize and articulate good theology, and I also wanted them to have all the tools they needed for the job. The weeks on critical thinking began to feel isolated from the rest of the course, and I would notice that those terms and structures were less and less present, both in the students' oral and written work and in my own classroom pontifications. And when I did draw attention to them I had an ominous sense too often of abandoning my subject matter. The beauty of theology, after all, is not "good argument," even if good argument is part of what makes theological language beautiful. My own theological rationale, rehearsed above, had made this clear from the first day of class: discursive reasoning is the path but not the destination. As Pavel Florensky put it, the understanding that faith seeks requires a "free act of ascesis," or a self-renunciation of human rational control in light of the discipline's goal, which is always earthly knowledge of the one who is defined as transcending earthly knowledge $(1997,45)$. Philosopher William Desmond refers to this intellectual deferral as the epistemic confrontation with an excessive "mystery of ontological generosity" $(1995,263)$. Well-crafted logic that loses track of the mysteriously generous God is no longer good theology. Was I fully conveying the beautiful mystery that had first drawn me to the discipline?

\section{From Conviction to Theology}

This line of questioning began what to date has been the biggest overhaul of that introductory theology course, which resulted in the flipped classroom experiment and new foundational assignment I describe below. My journey toward these experiments began, in fact, as I kept my eye on another goal of the class, which was to discover a new path toward integrating different voices into a discipline designed around a unified "system" of theology. Though describing this process fully would take a separate essay, I can summarize it easily enough. The discovery I eventually made, combining an insight from nineteenth century theologian John Henry Newman with a methodical tool of Thomas Aquinas, was that my teaching of both theology and critical reasoning needed to begin with the convictions that students were already bringing into the classroom.

This may seem like an obvious discovery, and for some no doubt it would have been and has been. I found myself in those early years battling for theological turf in classes where people had many firmly set and embedded theological convictions. For many, it seemed, a theologian was one who could "politely but firmly argue for the irrefutability of personal opinion" (Fisher 2017, 9). My notion early on was that in order to teach theology, which Augustine, Anselm, Florensky, and Barth all agree is a process of faith seeking understanding, I needed to make a distinction between these personal convictions students brought with them and the communal understanding we would be spending the semester seeking. I still teach this distinction, with an important difference: whereas before I said to the class that convictions are good in their own place, but that place was not theology class, now I say that convictions are the place to begin in theology, but not the place to end. More self-knowledge, more generosity.

When a student responds to a theological idea, for instance, with “I just don't think that God is like that," I once would have reminded her that "I just don't think" is a marker of a conviction, whereas an argument has to be a movement from a ground to a claim that the rest of us can follow. This is arguably a mild version of what Richard Crane (2016) calls "shock and awe" pedagogy, a mode of engagement common to many new professors, especially in disciplines like political science and theology where there is bound to be a lot of conviction entering the room on the first day of class. Better to disabuse them of these opinions, or at least bracket them outside the classroom space, so that new learning can happen.

The more time I spent trying to separate these two layers of language, however, the more I began to realize the importance of moving more fluidly between them. Rather than just bracket these convictions, I needed to invite students, as Stone and Duke put it, to give "serious second thought to their embedded theologies" $(1996,21)$. I began asking for more information. Why do you think that God isn't like that? What does it imply for other beliefs if God is or is not like that? This helps me reconfigure their conviction not as "their theology" (since theology is a communal language I avoid that phrase entirely), but rather as their theological "home." I then challenge them to see the theology classroom itself as a journey beyond that home, 
where their native way of articulating an idea meets with the ideas of others, and changes as a result of the journey. As Fisher noticed of the students in her classroom, "the irrefutability of personal opinion" is often the thing that keeps students within any discipline of thought from "leaving home” $(2017,10)$.

For a couple of years I dropped the disputation altogether, and instead tried to begin each class session with a disputation-style question. I would then attempt to walk the ones who volunteered answers through some "leaving home" steps, even if in the end they returned to the same conviction: they would now hold it more "deliberately." Or so my thinking went. What we were in fact practicing, of course, was the application of critical thinking to our ideas, making our convictions into theology. Still, though, I needed to free up some classroom space to teach my students how to make such inquiries, and how to answer them, so that they could become not just defenders of their convictions but self-aware theologians. And how to do this, when I also felt the need to exegete class readings and demonstrate the character of good theology, to the best of my ability, in lectures? As the program's systematician, I felt myself to be the last line of defense in ensuring that our graduates went into their vocations with proficiency in a classically formed and contemporarily attuned language of theology.

\section{Flipping the Theology Classroom}

This was the point at which I decided to try an experiment in flipping my systematic theology class. Flipped classrooms are those in which activities "that have typically and traditionally happened inside the classrooms now occur outside of the classrooms and vice versa” (McNally et al. 2017, 282). Characteristically,

a. students learn content before coming to class,

b. are evaluated based on their learning, and

c. this frees up class time to "focus on higher-level cognitive activities involving active learning, peer learning, and/or problem solving." (McNally et al. 2017, 282)

I came to this idea through conversations with my colleagues, through studying the online materials of a pedagogy institute based just across the street from me (University of Texas at Austin 2019), and also through conversations with a facilitator of an innovative learning collaborative housed at my seminary.

The background for flipped classrooms in the philosophy of education stems from socio-constructivist models of learning, in which students learn while, rather than before, doing (Steen-Utheim and Foldnes 2018). The literature often contrasts the teaching-centered lecture model with the learning-centered engagement model, a contrast that in my experience can be overstated. For instance, one article characterizes the lecture-based (teaching-centered) mode as "transmissive and passive, with little room for student participation" (Steen-Utheim and Foldnes 2018, 308). This has not been my experience. Coming out of graduate school in the early 2000s, and beginning my first full-time job in 2003, I was given several resources for beginning my work not only in research but also in teaching. I first heard the term "learning-centered classroom" in my first job, a full-time visiting lecturer position in the religious studies department at Indiana University-Purdue University of Indianapolis, where a major Lilly grant had given the university the resources to overhaul their entire curricular framework. A professor in the department, who came to review me in my first semester, suggested that I not try to engage students by offering verbal fill-inthe-blank questions, but rather through open-ended ones that would air their insights and allow them to give some shape to the classroom conversation. A year later, when I arrived at my current institution to begin building a theology syllabus, I had already begun practicing an interactive style of lecturing in which I watched carefully for learning-cues from students, and in which interruptions and student questions could revise and redirect the content covered on any given day.

I would not say, then, that my lecture-based classroom was deficient in student participation. Still, I had begun to diagnose a lack of learning, as described above. Somewhere between the active participation of students, which my format made space for, and my revised learning objective to help students "formulate multifaceted responses to complex theological questions," a rift had opened.

The flipped model in fact goes beyond student participation and aims at giving students ownership of their learning (SteenUtheim and Foldnes 2018, 308). Among other things, this ownership involves a meta-layer to actual learning: students not only learn new material, they learn about learning that new material. This is the pedagogy I was searching for. As an aid to con- 
necting their embedded convictions to deliberative theological reasoning, I wanted to bridge their already substantial participation in class with my aspirational goal of seeing them grow as self-aware theological reasoners. So I turned to a new pedagogical model as an experiment in this double bridge-building.

The innovative collaborative mentioned above was a great help to me. Our seminary recognizes the need for education and formation of priests who cannot, for various reasons, uproot and attend a residential seminary. What we offer them is a hybrid of distance learning and local facilitation. Professors from campus, myself included, design courses in our various fields, record lectures, and provide written discussion guides which we send to participating dioceses across the United States. Local teachers and facilitators then lead students through the material and foster the classroom discussions and other activities which facilitate student learning. In essence, the model relies on the "flip" described above, as students review and study the recorded lectures and discussion questions between classes and then engage the material together with their local facilitators when the class convenes. ${ }^{2}$ In a conversation with the instructor $^{3}$ from one diocese, a veteran of the classroom who also happens to be a former student of mine, he explained the exercises and activities that he used to help students get the most out of my recorded lectures. I then began reflecting on how I could imitate and adapt what he was doing in the hybrid version in my campus-based classroom.

The entire process took several years. At first I wrote my lectures out and posted them for students to read before class. Only after several attempts to get students to engage deeply with the material did I come to the conclusion that they were missing key theological content by skimming or simply failing to comprehend the lectures. In a systematic theology course with no text book other than the primary readings I used to enhance and complexify my lecture, this felt like a crisis. I began to observe the learning dynamic that so often reveals second rate pedagogy: the clever students and self-starters were learning really well, while the others were basically confused. No one, yet, was learning about their own theological learning.

So, in conversation with a particularly creative teaching assistant, I finally completed the flip for the Spring of 2018 , which is the semester I describe in what follows. ${ }^{4}$ My final product, coordinated to the criteria for a flipped classroom listed above, looked like this:

a. I recorded a lecture on each theological topic and made viewing it, along with readings, part of the assigned work prior to class time.

b. I Included an assignment in the syllabus called "Pop Interpretations," which involved a three-minute summary of the lecture by one student, followed by a brief response from another student. Responses could include disagreement, additions, or varying interpretations of the main themes.

c. After the interpretation and response, I opened the floor for discussion, and this generally was about both the theological ideas and the structure of the arguments in the lecture. Early in the semester, during the "prolegomena" unit on faith and reason, I framed human reasoning as a theological topic in the way I outlined above, and gave an introduction to the parts of an argument. As the semester went on I returned to this periodically. I could pause in the midst of, say, a discussion of the doctrine of the Trinity and invite students to identify grounds, warrants, claims, qualifiers, and internal rebuttals in what I or one of their classmates had said. And I could do this without worrying that we were missing essential theological content, since not only had I given this to them in the recorded lecture, but I had assessed their facility with the information in the Pop Interpretation exercise.

\section{Good Questions}

The second innovation I made was to alter the content within this altered form. As I said, I had shifted from thinking of faith convictions as non-theology to thinking of them as pre-theology. I did some work with a colleague who has read more deeply in pedagogy than I, and together we began shaping something I called the "Good Question" assignment, drawing especially from work he had done in cofounding a new model for a business school at the University of Texas. ${ }^{5}$

The assignment came to the students in an algorithm in which how they answered one question about a faith conviction would de-

\footnotetext{
2 Rev. Dr. John Lewis is, among other things, the Director of the lona Collaborative (the learning initiative I describe above) at Seminary of the Southwest. I am grateful for his suggestions on how to better describe the Collaborative for this article.

3 Rev. Robert Pace, rector of Saint Andrew's Episcopal Church in Amarillo, Texas, is the instructor I describe above, and was generous in sharing his teaching resources and creative materials with me.

4 My pedagogical shifts, along with the research for this article, owe a great deal to Andrew Green, Seminary of the Southwest MDiv class of 2018.

5 Steven Tomlinson is the Associate Professor of Leadership and Administration at Seminary of the Southwest, and cofounder of the Acton School of Business.
} 
termine how they answered the next. The point was to allow them to work their way to a point of perplexity, what Alisdair Maclntyre calls an epistemological crisis $(1988,362)$, and what I called "the frontier of your theological understanding." The crisis is the collision of incoherencies that leave the thinker with the sense of being stuck, or acknowledging that "there seem to be insufficient or no resources within the established fabric of belief" for moving toward a unified and coherent idea (Maclntyre 1988, 362). My explanation suggested that when a professor responds, "That's a good question," what it usually means is "I'm a little confused on how to answer that." It was that point of confusion, I said, that I wanted their convictions to reach.

The first step was for the student to identify a question. I suggested, though did not require, that they follow the disputatio methodology and ask a question that requires a yes or a no. For example, one student identified the question, "Can humans influence God?" 6

The second step was to determine if the question matters. That is admittedly a broad and subjective criterion, but the point of the assignment after all was to put their convictions into motion, so I began with the assumption that they felt some energy or pressure around whatever they were asking. If they answered no, I suggested they find a better question. If they answered that they were unsure, I asked them to break the question down into parts, and see if any of them called up convictional energy. In our example, the student decided that it did: "It matters whether or not we influence God because our ability to influence or not helps define our relationship with God."

In the third step the student was to observe and name the answer they felt some initial pressure to give, the embedded or "gut level" response. This was the context for the articulation, and perhaps discovery, of a conviction. In our example, the student's gut response to her own question was: "I want to think that humans influence God. Humans influence each other in relationships, and in general, the stronger the relationship, the greater the influence.”

A fourth step was to notice if they felt, or could imagine someone feeling, some pressure to answer in the opposite way. This was key. Many students initially turned in questions that were crafted as rhetorically stylized assertions, for which only one answer could be morally or theologically defensible. "Should Christians be members of hate groups?" is one imaginary example. I suggested that the ability to observe this opposing pressure is essential to the asking of a good question. ${ }^{7}$ In our example, the student noticed that "The problem here is that God is God, not just another human being. Since God doesn't change, it would seem like humans cannot influence God, since influence implies at the very least a change of heart or mind or emotion as a result of another."

Finally, I asked students to put both their initial conviction and the opposing conviction into argument format. I adapted the groundwarrant-claim model from Murphy (2004) into an if-and-then format. So "If God created people so we can be in relationship with God, and influence is a part of all relationships ..., then we can influence God." On the other hand, "If God is changeless in all ways ... and influence produces change as a result of the actions of another, then we cannot influence God."

The initial assignment ended with this statement of conflicting arguments. The next ones picked it up from there. I asked students to take notes from the texts of other theologians who had commented on their issue or a related one, and I asked them to formulate a "Good Answer" that dealt sufficiently and creatively with the conflicting arguments they had discovered. (Actually, I made this latter due prior to the research notes, but as several students pointed out both during the semester and in course evaluations at the end, this did not make much sense, as the Good Question assignment ended in too much perplexity to answer cogently without first bringing other voices into the conversation.) Finally, I asked them to put all the parts together in a constructive theology research paper: Ask a good question motivated by your own convictions, show why it is difficult to answer, engage with sources to show what shifts or "loosens" in the discussion and so allows a new response, and use the argument structure to make a good answer that responds to the complexity.

\section{Results}

The grades for these assignments indicated that it was no longer just the most able students who were benefiting from the changed format. Ten of the fourteen students received an A or B on the Good Question assignment, which came in the first half of the semester. While there were fewer A's on the final paper, which integrated their Good Questions, research notes, and Good Answers, the overall learning increased, with only two students falling below the $B$ range.

\footnotetext{
6 In what follows I have selected excerpts, with the author's permission, from the Spring 2018 class paper of Bryn Cadell, MDiv class of 2020 at Seminary of the Southwest.

7 The "ability to temporarily suspend one's own convictions is a hallmark of good actors," as a text on academic writing reminds, and it is a hallmark of good argument as well (Graff and Birkenstein 2014, 31).
} 
Course evaluations demonstrated some mixed feedback. The numerical data from the learning outcomes is included here as an appendix. Some of the negative feedback seems attributable to the strangeness of the flipped experience. There was some frustration with the videos and preparation, and also some complaints about the anxiety raised by the Pop Interpretations assignment. The three "partly achieved" scores I received (one for the first learning outcome and two for the second) correlated to confusing and disconnected assigned readings. This was an issue I noticed as well, early in the semester. I had not anticipated how the flip would necessitate a change in the readings. The syllabus still contained some texts each week that, while on theme, were not connected in any obvious way to the salient points of my recorded lectures. These were the kind of readings that professors sometimes put in just because "it's good for you." Where my old interactive lecture model could wander in and out of these readings as students asked questions about them and then lead back to my salient points, now the non-interactive video format, combined with class discussion steered entirely by students' commentaries on that video, meant that anything I could not coordinate clearly within my lecture was simply going to be confusing.

In the evaluation comments, responding to "If you were teaching this course, what would you do differently?" a student wrote, "The videos were helpful but excessive. I think we spent too much time reading, watching videos, and preparing for pop interpretations." Another commented that the videos were helpful because you cannot pause and go back over select parts of a live lecture.

In response to "What was most surprising about this course?" one student said, "How challenging it is to build arguments." If understanding the challenge is a step toward accomplishing it, then I read that as significant of theological growth. Another said, "How theology seemed to bring out creativity in some of my classmates. And how much fun it was." Those are the ones we like to read. Another said, "The pop quizzes - but, I was always prepared to get up and present, so, very effective." My reading there was that the student was initially surprised to be given pop quizzes in a graduate school classroom, but still conceded their usefulness. Another student answered, "That the course was focused on our own theologies a little more than studying historical ones." I took this, perhaps, in a more affirmative way than the student meant it, having so carefully constructed my course to make it more about the constructing of theology than the study of theological history (though I cringed a bit, I admit, at the phrase "our theologies").

In response to the question, "What will you take away from this course?" a student said, "How to play with questions." Another said, "The ability to engage in theological discussion with appropriate reasoning." Responses to "What you would change?" brought some critique of the varied length of videos, the Pop Interpretations, and especially the complexity of some of the readings.

For me, however, the most meaningful evidence, as is often the case, was anecdotal. In the Pop Interpretation exercise with which the first day of class each week began, students were more or less capable of summarizing the video lectures early on. Sometimes they would point to theological formulations they found interesting or confusing, sometimes they would home in on what seemed like a key argument. Less often, they could do both. In the final weeks, however, there was a kind of soft mutiny taking place in the classroom. Rather than waiting for me to show up and appoint someone to summarize, students began arriving early and, one by one, taking the initiative to appoint themselves the day's interpreter. Each of the last three weeks I walked in to a white board full of phrases, diagrams, and sometimes theological cartoons. They made it a game to see if I could guess from the board which student had done it. That was a lot of pressure, and I think I was zero for three.

What I observed in those weeks was an integration of a semester's worth of material into careful discernment of the lecture's theological and critical structure. They were mapping my lectures on Ecclesiology and Eschatology onto previous lectures on Trinity and Christology, and doing so by means of grounds, claims, and warrants. In doing so, they demonstrated for one another how carefully structured reasoning can become a human way of thinking toward a divine and transcendent mystery. They were discovering that a faith seeking understanding is not necessarily an attempt to congratulate God on being so reasonable.

Moreover, they were discovering that this act of understanding is also not necessarily an attempt to shut down conversation. These interpretations generated arguments about such themes as the viability of claims for universal salvation and the presence of Christ in the bread and wine. In other words, I was hearing difficult and potentially anxiety-producing topics rendered into generous discussion by future leaders of theological communities. It was an explosion of deliberative theology like I had not seen before in my fifteen years of teaching.

Comparison with earlier semesters is difficult, since not only had I made changes over the years in the learning outcomes, our faculty also made changes to the course evaluations. So I was asking new and more focused questions about my changing course. For this reason, I consider this "Year One" of the experiment, and will evaluate future semesters against this one. In the meantime, the anecdotal evidence combined with the grades and evaluations leads me to conclude that the course was a successful step toward achieving the goals in student learning as I articulated them. My growing edges are largely about perfecting the model: next steps include 
re-making videos of uniform length (no more than thirty minutes), and editing readings so that they are in a more introductory vein unless I plan to take class time to exegete them carefully and integrate them into the course content. But the success was evident. I was watching students learn theology, and also learn about their own theological learning. They were more prepared to be creative and insightful and even spontaneous practitioners of theology, in my estimation, than any single class I had previously taught. And they were some having fun doing it.

\section{BIBLIOGRAPHY}

Baker, Anthony. 2018. “Constructive Theology.” Syllabus, Seminary of the Southwest, Austin, TX. https://www.wabashcenter. wabash.edu/selected-resources/?post_ids=229353.

Birkenstein, C., and R. Durst. 2014. They Say, I Say: The Moves that Matter in Academic Writing. New York, NY: W.W. Norton and Company.

Crane, R. D. 2016. “Method, Maclntyre, and Pedagogy: Inviting Students to Participate in Theology as a Living Conversation.” Teaching Theology \& Religion 19, no. 3: 222-44.

Desmond, William. 1995. Being and the Between. Albany, NY: SUNY Press.

Fisher, K. M. 2017. “Look Before You Leap: Reconsidering Contemplative Pedagogy.” Teaching Theology \& Religion 20 , no. 1: 4-21.

Florenksy, P. 1997. The Pillar and Ground of the Truth. Translated by B. Jakim. Princeton, NJ: Princeton University Press.

MacIntyre, A. 1988. Whose Justice? Which Rationality? Notre Dame, IN: University of Notre Dame Press.

McNally, Brenton, Janine Chipperfield, Pat Dorsett, Letitia Del Fabbro, Valda Frommolt, Sandra Goetz, Joanne Lewohl, et al. 2017. “Flipped Classroom Experiences: Student Preferences and Flip Strategy in a Higher Education Context.” Higher Education: The International Journal of Higher Education Research 73, no. 2: 281-298.

Murphy, N. 2004. Reason and Rhetoric in Religion. Eugene, OR: Wipf and Stock.

Seminary of the Southwest. 2019. “Conversation Covenant.” https://ssw.edu/conversation-covenant/.

Steen-Utheim, A. T., and Foldnes, N. 2018. “A Qualitative Investigation of Student Engagement in a Flipped Classroom.” Teaching in Higher Education 23, no. 3: 307-24.

Stone, Howard W., and James O. Duke. 1996. How to Think Theologically. Minneapolis, MN: Fortress Press.

University of Texas at Austin. 2019. Faculty Innovation Center. https://facultyinnovate.utexas.edu/. 


\section{APPENDIX}

Course Learning Outcomes, Constructive Theology Spring 2018

\begin{tabular}{|l|l|l|l|l|}
\hline Learning Goal & Achieved & Mostly Achieved & Partly Achieved & Not Achieved \\
\hline $\begin{array}{l}\text { Articulate and explain the } \\
\text { key topics of Christian } \\
\text { theology }\end{array}$ & 3 & 10 & 1 & 0 \\
\hline $\begin{array}{l}\text { Critically and charitably } \\
\text { analyze complex theolog- } \\
\text { ical questions }\end{array}$ & 4 & 8 & 2 & 0 \\
\hline $\begin{array}{l}\text { Formulate multifaceted } \\
\text { responses to complex } \\
\text { theological questions }\end{array}$ & 4 & 10 & 0 & 0 \\
\hline $\begin{array}{l}\text { Formulate and respond } \\
\text { to a theological question } \\
\text { in dialogue with other } \\
\text { theologians }\end{array}$ & 5 & 9 & 0 & 0 \\
\hline
\end{tabular}

\section{ABOUT THE AUTHOR}

Anthony Baker is the Clinton S. Quin Professor of Systematic Theology at Seminary of the Southwest in Austin, Texas, where he has taught since 2004. He also serves as Theologian in Residence at Saint Julian of Norwich Episcopal Church. His publications include Diagonal Advance: Perfection in Christian Theology (SCM 2011), Shakespeare, Theology, and the Unstaged God (Routledge, forthcoming), and various articles and chapters in journals and edited collections. 
